\title{
Rapid assessment of expansion of nursing, paramedical and public health education and it's implication on quality of education
}

\author{
Md. Talukder H K, Nazneen R, Md. Hossian Z, Akther N, Chowdury I J, Parvin I A \\ Centre for Medical Education, Mohakhali, Holy Family Red Cresent Medical College \\ Sapporo Dental College, Dhaka Medical College, Dhaka Shishu Hospital, College of Nursing, Mohakhali, Dhaka
}

Correspondence address : Dr. Md. Humayun Kabir Talukder, Associate Professor, Centre for Medical Education (CME), National Health Library Building, Mohakhali, Dhaka-1212

E-mail: hktalukder@yahoo.com

\begin{abstract}
Introduction: Bangladesh is facing many challenges in health care that are similar to other developing countries. In Bangladesh standard of paramedical, nursing, pharmacy and public health education are expanding rapidly which needs to call for assessment and evaluation to be up to date in the respective fields. Study aims to assess the expansion of Nursing, Paramedical \& Public health Education in Govt. \& non Govt. sectors \& it's implication on quality of education.

Methods: This was a descriptive type of cross sectional explorative study, conducted among the teachers and student of different institutes. Questionnaire was developed and a FGD was done. Then the data was analyzed.

Results: At present situation, the numbers of non govt. organizations are more than govt. organizations (127 vs. 85). SWOT analyses showed the overall strength of the institutions were the scope for further improvements and the political commitments for expansion. Weaknesses lie in the lack of adequate infrastructure, suboptimal technical and laboratory facilities and teaching staffs. Opportunities were, increasing demand and provision of jobs at home and abroad. Possible threats were loss of quality services, recognition and registration of the institutes. Regarding the overall organization of the courses, $43 \%$ of the students voted as good and $100 \%$ of the teachers showed positive opinion. Regarding the teaching-learning procedure, $41 \%$ of the teachers strongly agreed about the perfect selection of the students. $48.3 \%$ teachers agreed about the adequacy of the number of teachers. $47.8 \%$ students also agreed with the competency of the teachers. Nearly one third teachers as well as students agreed about the good physical environment of the institute. About $35 \%$ and $36 \%$ of the teachers and the students respectively agreed about the transparency of the assessment systems.
\end{abstract}

Conclusions: Present Bangladesh Govt. has implemented various initiatives regarding health sector reform. Proper funding, management, monitoring and evaluation can improve present situation and thus help in the development of better institutional output.

Key Words: Quality assessment, Nursing, Paramedical, Public health Education. 


\section{Introduction}

Bangladesh has a population of 140 million. While still a developing economy, recent years have seen significant improvements in health and social development.

Life expectancy has increased from 45 to 63 between 1975-2004. The Human Development Index (HDI), which combines life expectancy, school enrolment and GDP per capita, has increased from 0.35 to 0.53 between 1975 -2004 .

Bangladesh now ranks 137th out of 177 in the world. ${ }^{1}$ Infant mortality has declined steadily from 92 per thousand live births in 1992 to 53 in $2002 .^{2}$

Maternal mortality has also reduced significantly and it is on the way to achieve the Millennium Development Goals (MDG) set by the United Nations. ${ }^{3}$ Oral Rehydration Solution (ORS) was developed and popularized in Bangladesh. It has been credited with saving 40 million lives worldwide. ${ }^{4}$ The micro-credit movement pioneered by Grameen Bank and Prof Yunus is now a global phenomenon and directly resulted in improvement of health care at the grass-root level. ${ }^{5}$ Most of these successes have been driven by active participation from government and non-government organizations.

However, Bangladesh is facing many challenges in health care that are similar to other developing countries. High population density, rapid urbanization, aging population, Emigration of qualified health care personnel, changing disease pattern, financial constraints, corruption, and inefficiency constantly pressurize an overburdened health care delivery system. This is compounded by a significant shortage and mal-distribution of qualified doctors in the country. There are approximately 38,000 physicians in all giving a ratio of 26 per 100,000 population (compared to for example 230 per 100,000 in the UK). ${ }^{6}$ Many of the qualified doctors are concentrated in the few urban centres leaving rural areas chronically short of doctors. In Bangladesh standard of paramedical education and practices is looking after by The State Medical Faculty of Bangladesh, Nursing Education \& practice is looking after by Bangladesh Nursing Council \& Pharmacy education is looking after by Pharmacy Council. Graduation and post graduation education are looking after by undergraduate \& postgraduate faculty of medicine of concerned universities respectably \& standard of practices by BM\&DC. There was huge growth in the field of nursing, paramedical \& public health education in Bangladesh in the last 2 years. So it is very essential to have a rapid assessment of expansion of nursing, paramedical \& public health education in govt. \& non govt. sectors \& it's implication on quality of education. As we can see in India, only government or trust hospitals can set up education facilities. According to the guidelines of the Medical Council of India (MCI), they have specifications as to the amount of land required, the number of classrooms, and on their size before the hospitals can actually be set up. The healthcare education facility is required at a minimum have a 10- acre campus. The Nursing Council does not allow private players to enter into nursing education unless they form trusts. Hospitals need to tie up with another organization in order to grant a PG diploma in hospital administration. Again, there are requirements on land and infrastructure, such as requiring a 500 seater auditorium, 25 acres of contiguous land, conditions which are difficult to fulfill in first tier cities. 7 The technical vocational training has an overlapping three tier system, comprising of craftsman level training offered by technical schools and institutes. The training covers; Business, Technical Vocational, Health, Agriculture and Paramedical and Para-professional fields. It comprises of public institutions, private service providers, apprenticeships and enterprise based training programmes. ${ }^{8}$ The rapid expansion in the educational field in this training areas needs to call for assessment and evaluation to be up to date in the respective fields. Study aims to assess the expansion of Nursing, Paramedical \& Public health Education in Govt. \& non Govt. sectors \& it's implication on quality of education. Also to identify the present status among these institutes in Bangladesh.

\section{Methods}

A descriptive cross sectional explorative study was conducted among the teachers and students of different government and non government nursing, paramedical and public health institutes of Bangladesh who were available at the time of data collection.

After initial extensive literature review, three types of selfadministered structured questionnaires were prepared for teachers and for students separately. Data were collected by the investigators \& data collectors. An initial introduction and explanation was given to all respondents before giving the questionnaire to fill up.

Focus Group Discussion (FGD) was done to collect indepth information and to update the draft report. All the data were checked and edited after collection. Then the data were entered into computer and was analyzed. 


\section{Results}

Table 1: Present situation of the Nursing, Paramedical \& Public health Education in Bangladesh.

\begin{tabular}{|c|c|c|c|c|c|c|}
\hline Name of the institution & $\begin{array}{c}\text { Number } \\
\text { of } \\
\text { Institution }\end{array}$ & & & $\begin{array}{c}\text { Number } \\
\text { of seats } \\
\text { per year }\end{array}$ & & \\
\hline & Total & Govt. & Non Govt. & Total & Govt. & $\begin{array}{l}\text { Non } \\
\text { Govt }\end{array}$ \\
\hline Institute of health technology - & 51 & 3 & 48 & 6956 & 1010 & 5946 \\
\hline IHT conducting BSc Courses & 16 & 03 & 13 & 1175 & 110 & 1065 \\
\hline IHT conducting MSc courses & 2 & 0 & 2 & 65 & & \\
\hline MATS & 32 & 07 & 25 & 2505 & 650 & 1855 \\
\hline Nursing institutes conducting diploma courses & 69 & $\begin{array}{l}35 \text { (old) } \\
12 \text { (new) }\end{array}$ & 22 & 2570 & $\begin{array}{l}15409 \\
\text { (old360(new) }\end{array}$ & 670 \\
\hline Nursing colleges & 07 & 4 & 3 & 520 & 400 & 120 \\
\hline $\begin{array}{l}\text { Nursing colleges conducting } \\
\text { BSc nursing courses }\end{array}$ & 13 & 6 & 7 & 765 & 550 & 215 \\
\hline $\begin{array}{l}\text { MPH courses offered by NIPSOM, } \\
\text { govt. medical colleges ( DMC, SSMC, MMC, CMC, } \\
\text { RjMC, RgMC) and private universities - (BRAC, } \\
\text { North South Univ., State Univ, Atish Dipankor } \\
\text { University)- }\end{array}$ & 12 & $\begin{array}{l}6 \text { medical } \\
\text { colleges }\end{array}$ & $\begin{array}{l}7 \\
\text { universities }\end{array}$ & & & \\
\hline MPhil courses offered by NIPSOM, & 2 & & & & & \\
\hline CHW training centres- & CHW & 9 & & 650 & & \\
\hline & 212 & 85 & 127 & 14491 & 4620 & 9871 \\
\hline
\end{tabular}

Table 1 Shows the present situation of the Nursing, Paramedical \& Public health Education in Bangladesh. The number of non govt. organizations are much more than govt. organizations (127vs 85).

Table 2: Situation Analysis

\begin{tabular}{|c|c|c|c|}
\hline & Paramedical Education & Nursing Education & Public Health Education \\
\hline Strength & $\begin{array}{l}\text { Political support present. } \\
\text { Existing number of institutes are } \\
\text { not negligible. } \\
\text { Positive Private sectoral } \\
\text { initiative. }\end{array}$ & $\begin{array}{l}\text { Highest political commitment } \\
\text { Institutes conducting diploma and } \\
\text { BSc. nursing courses are working } \\
\text { well. }\end{array}$ & $\begin{array}{l}\text { Courses offered by the } \\
\text { following institutes : } \\
\text { NIPSOM , } 6 \text { govt . medical } \\
\text { colleges and } 7 \text { Private } \\
\text { universities. }\end{array}$ \\
\hline Weakness & $\begin{array}{l}\text { Sub optimal infrastructure in } \\
\text { institutes. } \\
\text { No organogram. } \\
\text { Teaching staffs and aids are not } \\
\text { sufficient. } \\
\text { Transparency regarding students } \\
\text { admission not maintained. }\end{array}$ & $\begin{array}{l}\text { Lack of infrastructures. } \\
\text { Inadequate number of qualified } \\
\text { teachers, teaching aids and } \\
\text { supporting staff. } \\
\text { Inadequate clinical training, } \\
\text { facilities in library and } \\
\text { laboratories. } \\
\text { Financial problem. }\end{array}$ & $\begin{array}{l}\text { Inadequate and less qualified } \\
\text { teaching staff . } \\
\text { Inadequate practical training. } \\
\text { MPH courses at non govt } \\
\text { universities are yet to be } \\
\text { recognized by BM\&DC. }\end{array}$ \\
\hline
\end{tabular}




\begin{tabular}{|c|c|c|c|}
\hline Opportunities: & $\begin{array}{l}\text { Possibility of further expansion. } \\
\text { Growing interest among the } \\
\text { students. } \\
\text { Provision of jobs at home and } \\
\text { abroad. } \\
\text { Increased health manpower. }\end{array}$ & $\begin{array}{l}\text { More demand of nurses within the } \\
\text { country and abroad }\end{array}$ & $\begin{array}{l}\text { Increasing number of public } \\
\text { health experts. } \\
\text { Infra structure facilities } \\
\text { present. } \\
\text { Public sectors can run evening } \\
\text { and holiday courses. }\end{array}$ \\
\hline Threats: & $\begin{array}{l}\text { Possibility of loss of quality } \\
\text { services. } \\
\text { Possibility of commercialization } \\
\text { by the owner of the non govt. } \\
\text { institutes. } \\
\text { Conflict between SMFB, MOH } \\
\text { \& FW and education ministry } \\
\text { regarding recognition and } \\
\text { registration of the institutes. }\end{array}$ & $\begin{array}{l}\text { Produced nurses are less } \\
\text { competent in terms of clinical and } \\
\text { communication skill. } \\
\text { Less commitment to nursing } \\
\text { profession and empathetic } \\
\text { behavior. }\end{array}$ & $\begin{array}{l}\text { Quality education will be } \\
\text { lost. }\end{array}$ \\
\hline Possible effects : & $\begin{array}{l}\text { Paramedical manpower } \\
\text { deficiency will be less and } \\
\text { eventually be met. } \\
\text { Reduced quality of the } \\
\text { technologist }\end{array}$ & & $\begin{array}{l}\text { Sub standardization } \\
\text { Community service. } \\
\text { More harm to the society } \\
\text { rather than improvement. }\end{array}$ \\
\hline $\begin{array}{l}\text { Recommendations } \\
\text { for improving the } \\
\text { existing situation: }\end{array}$ & $\begin{array}{l}\text { Needs immediate assessment. } \\
\text { Proper monitoring and } \\
\text { supervision by local and as well } \\
\text { by higher authority. } \\
\text { Proper lab facilities, quality } \\
\text { assurance and training of the } \\
\text { students must be assured. } \\
\text { There must be proper } \\
\text { organogram and staff pattern } \\
\text { accordingly. } \\
\text { Govt. as well the private sector } \\
\text { must expand according to } \\
\text { country need. }\end{array}$ & $\begin{array}{l}\text { Recognition of the nursing } \\
\text { profession as a vital part of health } \\
\text { care delivery system. } \\
\text { Provision of equal opportunities } \\
\text { for development. } \\
\text { Creation of more posts for teacher } \\
\text { in different institutes . } \\
\text { Development of a career plan } \\
\& \text { up-gradation for nursing } \\
\text { profession. } \\
\text { Conceptual reorientation on } \\
\text { nursing profession for nurses \& } \\
\text { medical professionals. } \\
\text { Regularization of the promotion } \\
\text { system. } \\
\text { Creation of adequate posts for all } \\
\text { level of nursing profession. } \\
\text { A quality assurance system is to } \\
\text { be established \& monitored. }\end{array}$ & $\begin{array}{l}\text { Number of post should be } \\
\text { increased in government \& } \\
\text { private sector . } \\
\text { Expert personnels should be } \\
\text { placed at appropriate places . } \\
\text { There should be proper } \\
\text { promotion policy for govt. } \\
\text { sector. } \\
\text { More scope of community } \\
\text { based public health teaching- } \\
\text { learning and practical training } \\
\text { should be created. } \\
\text { Initiative for recognition from } \\
\text { BM\&DC } \\
\text { Number and quality of } \\
\text { teachers should be according } \\
\text { to BM\&DC regulations. } \\
\text { Standardization and } \\
\text { upgradation of the } \\
\text { Curriculum. } \\
\text { Exchange of faculties between } \\
\text { Govt. public and private } \\
\text { institutes. }\end{array}$ \\
\hline
\end{tabular}




\begin{tabular}{|c|c|c|}
\hline $\begin{array}{l}\text { Recommendations } \\
\text { for maintaining } \\
\text { quality of education } \\
\text { : }\end{array}$ & $\begin{array}{l}\text { Teachers must be competent } \\
\text { and recruited as per SMFB } \\
\text { guidelines. } \\
\text { Students must be admitted } \\
\text { according to merit. } \\
\text { Curriculum should be followed } \\
\text { meticulously and reviewed } \\
\text { periodically to make it need } \\
\text { based. } \\
\text { Teacher should be evaluated } \\
\text { time to time for improvement of } \\
\text { teaching. }\end{array}$ & $\begin{array}{l}\text { There should be a central } \\
\text { body for monitoring the } \\
\text { standard of curriculum, } \\
\text { teaching learning, students } \\
\text { intake, assessment, } \\
\text { community based teaching } \\
\text { and learning. } \\
\text { Quality assurance scheme } \\
\text { to be developed and } \\
\text { implemented. }\end{array}$ \\
\hline
\end{tabular}

Table 2 Shows the SWOT analysis of different level of education in Bangladesh.

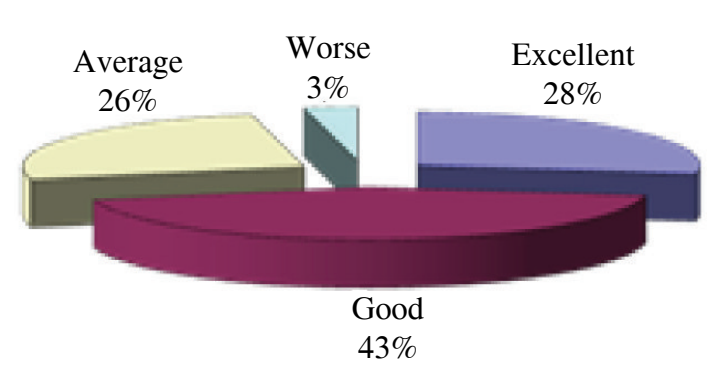

Fig. 1: Distribution of the respondents (students) as per their opinion about overall organization of their course.

The opinion expressed as excellent $28 \%$ (100), good $43 \%$ (157), average $26 \%$ (94) and as worse only $3 \%$ (11).



Fig. 2: Distribution of the respondents (teachers) as per their opinion about overall organization of their course which showed $100 \%$ of the teachers had positive opinion.

Table 3: Distribution of the respondents as per their opinion about different events of their institutes and teachinglearning procedures. Teacher's $(n=29)$ and the Student's $(n=362)$ Views :

\begin{tabular}{|c|c|c|c|c|c|c|c|c|c|c|}
\hline \multirow[t]{3}{*}{$\begin{array}{l}\text { Different events of institutes } \\
\text { and teaching-learning }\end{array}$} & \multicolumn{10}{|l|}{$\begin{array}{l}\text { Different } \\
\text { levels of } \\
\text { Opinion }\end{array}$} \\
\hline & SA & & A & & $\mathrm{U}$ & & $\mathrm{DA}$ & & SDA & \\
\hline & $\begin{array}{l}\text { Teacher } \\
\%\end{array}$ & $\begin{array}{l}\text { Student } \\
\%\end{array}$ & $\begin{array}{l}\text { Teacher } \\
\%\end{array}$ & $\begin{array}{l}\text { Student } \\
\%\end{array}$ & $\begin{array}{l}\text { Teacher } \\
\%\end{array}$ & $\begin{array}{l}\text { Student } \\
\%\end{array}$ & $\begin{array}{l}\text { Teacher } \\
\%\end{array}$ & $\begin{array}{l}\text { Student } \\
\%\end{array}$ & $\begin{array}{l}\text { Teacher } \\
\%\end{array}$ & $\begin{array}{l}\text { Student } \\
\%\end{array}$ \\
\hline $\begin{array}{l}\text { Selection of the students is } \\
\text { perfect }\end{array}$ & 41.4 & & 37.9 & & 10.3 & & 10.3 & & - & \\
\hline $\begin{array}{l}\text { Number of the teaches are } \\
\text { adequate }\end{array}$ & 27.6 & 53.6 & 48.3 & 15.5 & - & 1.4 & 13.8 & 11.3 & 10.3 & 18.2 \\
\hline $\begin{array}{l}\text { Teachers of the institutes } \\
\text { are competent }\end{array}$ & 34.5 & 47.8 & 24.1 & 32 & 10.3 & 1.7 & 31 & 5.8 & - & 12.5 \\
\hline $\begin{array}{l}\text { Physical environment of the } \\
\text { institutes is good }\end{array}$ & 34.5 & 32 & 34.5 & 41.2 & - & 9.4 & 17.2 & 12.7 & 13.8 & 4.7 \\
\hline $\begin{array}{l}\text { Assessment system is } \\
\text { transparent }\end{array}$ & 34.5 & 29 & 10.3 & 36.2 & 24.1 & 7.5 & 31 & 7.5 & - & 14.6 \\
\hline
\end{tabular}


SA-strongly agreed, A- agreed, U- undecided, DA- disagreed, SDA- strongly disagreed

Table 2 shows the distribution of the respondents as per their opinion about different events of their institutes and teaching-learning procedures.

Selection of the students is perfect: Teachers: SA- 41\%, A-37.9\%, U- $10.3 \%$.

Number of the teaches are adequate: Teachers: SA-27.6\%, A- 48.3\%, DA -13.8\%, SDA- 10.3\%. Student: SA-53.6 \%, A-15.5 \%, U-1.4\%, DA- 11.3-\%, SDA-18.2 -\%.

Teachers of the institutes are competent: Teachers: SA- 27.6\%, A-48.3\%, DA-13.8\%, SDA-10.3\%. Student : SA-47.8 \%, A $-32 \%$, U- $1.7 \%$, DA- $5.8 \%$, SDA- $12.5 \%$.

Physical environment of the institutes is good: Teachers: SA- 34.5\%, A- 34.5\%, DA - 17.2\%, SDA- 13.8\%. Student: SA$32 \%$, A- 41.2\%, U- 9.4\%, DA - 12.7\%, SDA- 4.7\%, Assessment system is transparent: Teachers: SA- 34.5 \%, A- 10.3\%, U- $24.1 \%$, DA -31\%, Student ;SA- $29 \%$, A- 36.2\%, U - 7.5\%, DA- -7.5\%, SDA- $14.6 \%$.

\section{Discussion}

A country's health education system should produce an appropriately skilled workforce to address its health priorities. The education system helps to determine two key elements of that workforce: the number of graduates with a given skill set (e.g. physicians, nurses, pharmacists, laboratory technicians, paraprofessionals) and the quality of those human resources (e.g. knowledge and skills). In assessing the role of the education system for strategic planning and policy-making it is important to develop indicators of the quantity and quality of graduates educated in the health professions. ${ }^{9}$

To attain the major goals of MDG's Bangladesh has progressed on its way. There are a number of initiatives in the health sector reforms has been done. But the lack of adequate number of teaching staff and teaching facilities caused a compromise between the quality of services and education. The government should take measures to maintain the quality of education and should be supportive to both public and private institutes to achieve quality manpower to serve the health needs of the nation. We have developed the "Digital Bangladesh". Technology Enabled Learning can cause Improvement of Quality in Higher Education. As we can see, the Odisha state has the excellence in software, hardware and telecommunications through technology enabled learning, professionalism, training, software skills and business solutions. That's how the country should speed up and promote competitive dynamics through these IT innovations. For this purpose it is essential to build up suitable action plans.

In this context, the quality of Higher Education can be enhanced with the use of digital competencies which will result in paradigm shift in the teaching and learning process. It is argued that digital competence can be achieved only when we can address the changes of quantity and quality in our education system, issues of poor infrastructure, absence of good and trained teachers, and absence of relevance/ context. ICT in classroom enhances cognitive learning process significantly improving engagement in the classroom and retention of knowledge. Moreover, the thrill of technology is an added attraction for the learner. In view of this, stress should be on IT-enabled learning strategies. There should be an effort to promote and implement e-learning for building, networks of virtual classrooms through different programmes. ${ }^{10}$ Qualified teachers and trainers are the fundamental key to provide quality education to reach high standards in academic and vocational competencies. Their recruitment, remuneration, education, training and retraining, assignment and provision of adequate facilities are critical elements of any successful educational system. The assessment methodology should also be fair, linked to standards and be nondiscriminatory. Investing in skills development is the cornerstone of developing an employable and globally competitive work force. A skilled work force improves the investment climate because skilled workers create an attractive economic environment for investors. The icing to this should be macro-economic stability and continued improvements in governance, Important reforms to promote skills training need to be initiated both in the formal and informal sectors to reflect an integrated approach to education, training and employment. ${ }^{11}$

\section{Conclusion}

Present Bangladesh Govt. has implemented various initiatives regarding health sector reform. Proper funding, management, monitoring and evaluation can improve present situation and thus help in the development of better institutional output.

\section{References}

1. Doza B. Human Development Index (HDI) of Bangladesh in UN Report. December 2007. http:// 
bdoza.wordpress.com/2007/12/14/humandevelopment index-hdi-of-bangladesh-in-un-report/ Visited on 7.4. 2012.

2. UN Country Profile Bangladesh, 2007.11-12 http:// www.un.org/esa/agenda21/natlinfo/wssd/bangladesh. pdf. Visited on 8.4.2012.

3. Chowdhury. Lancet 2007; 370:1292-1293.

4. Geoff W. In pursuit of "humanitarian science. BMJ 2003; 327:7427-1308

5. Chavan P, Ramakumar R Micro-Credit and Rural Poverty . An Analysis of Empirical Evidence. Economic and Political Weekly. 2002; 955-965.

6. World health report. 2006 -working together for health. p.190. http://www.who.int/whr/2006/en/. Visited on 9.4.2012.

7. Wattal V. Identification Of Competition Issues In The Healthcare Sector In India. [Thessis M.A. (Economics) Part I] Gokhale Institute of Politics and Economics, Pune. May-June 2010: pp15. Available from- http://cci.gov.in/images/media/Research Reports/VasudhaWattalHealthcareSector.pdf. visited on 9.4.2012.

8. Technical and Vocational Education and training for the twenty first century UNESCO and ILO recommendations. Available from- http://www. unesco.org/education/. visited on 9.4.2012.

9. Bossert $\mathrm{T}$ et al . Assessing financing, education, management and policy context for strategic planning of human resources for health; World Health Organization 2007.

10. Richard C. Levin. Report of the Task Force on Higher Education Department of Higher Education. Govt of Odisha. 2009

11. PATRICK S. Towards meeting the challenges in the delivery of quality education and sports . Paper on the skills development presented during the education sector review 2010/11. 